\title{
Xiphinema index and its Relationship to Grapevines: A review
}

S. van Zyl ${ }^{1,3,4}$, M.A. Vivier ${ }^{1,2}$, M.A. Walker ${ }^{3 *}$

(1) Department of Viticulture and Enology, Stellenbosch University, Private Bag X1, Matieland (Stellenbosch), South Africa

(2) Institute for Wine Biotechnology, Stellenbosch University, Private Bag X1, Matieland (Stellenbosch), South Africa

(3) Department of Viticulture and Enology, University of California, 595 Hilgard Lane, Davis, CA, 95616, USA

(4) Current address: Department of Viticulture and Enology, California State University, 2360 East Barstow Avenue, Fresno, CA, 93740, USA

Submitted for publication: September 2011

Accepted for publication: October 2011

Key words: Xiphinema index, resistance, Grapevine fanleaf virus, DNA markers, rootstocks

\begin{abstract}
The dagger nematode, Xiphinema index, is considered a major pest in grape growing countries. Xiphinema index is especially important because of its ability to transmit Grapevine fanleaf virus when feeding on grapevine roots. This paper provides a comprehensive and updated review of the classification, genetics and biology of Xiphinema index, and its relationship with grapevine fanleaf virus. Current control measures, as well as past and present efforts to breed resistant grapevine rootstocks, are presented.
\end{abstract}

Grapevines are cultivated in temperate and Mediterranean climates around the world. Grapevines have been moved between countries and continents, following human migration and settlement, and have been imported and cultivated in numerous countries. These events have increased the incidence and spread of injurious pests and diseases (Esmenjaud \& Bouquet, 2009). Three major pests are known to attack the root system of grapevines: grape phylloxera (Daktulosphaira vitifoliae Fitch); ground pearls (Margarodes spp.); and a wide range of root-feeding nematodes. These pests damage roots, leading to their decay, the prevention of new root development and may result in vine decline and eventual death. The initial impact of these pests may not be severe, but the cumulative impact over years intensifies and causes significant losses (De Klerk \& Loubser, 1988). Nematodes associated with vine damage are root-knot nematodes (Meloidogyne spp.), citrus nematodes (Tylenchulus semipenetrans), root-lesion nematodes (Pratylenchus vulnus) and dagger nematodes (Xiphinema spp.) (Nicholas et al., 2007).

All of the nematodes that have an economic impact on grapevines are present in South Africa (Smith, 1977). Dagger nematodes are considered to be major pests (Brown et al., 1995), because they are often associated with woody plants and are generally associated with specific viruses, which they carry from plant to plant through feeding. More than 170 species of Xiphinema have been identified worldwide on a wide range of hosts. Sixty-nine Xiphinema species have been reported in South Africa, although only four were implicated in plant virus transmission: $X$. americanum Cobb, $X$. diversicaudatum Thorne, $X$. index Thorne and Allen, and
X. italiae Meyl (Loubser \& Meyer, 1987a); the first three are common in South African vineyards (Malan, 1995). They are found in a variety of soils and are migratory ectoparasites (Shurtleff \& Averre III, 2000). This review focus on $X$. index, its interaction with grapevines and its role as vector for grapevine fanleaf virus (GFLV).

\section{Classification, description and identification of Xiphinema index}

Xiphinema index is in the order Dorylaimida, suborder Dorylaimina, and superfamily Dorylaimoidea, family Longidoridae, subfamily Xiphineminae and genus Xiphinema (Taylor \& Brown, 1997). The genus Xiphinema was first described by Thorne (1939) and $X$. index was first identified and described by Thorne \& Allen (1950).

The body of an adult female $X$. index is about $3 \mathrm{~mm}$ long. The lip region is hemispherical and almost continuous along the body. The odontostyle is approximately $126 \mu \mathrm{m}$ long, the odontophore $70 \mu \mathrm{m}$ and has large flanges. There is a guide ring at approximately $108 \mu \mathrm{m}$ from the anterior end (Decraemer \& Geraert, 2006). The female body is elongatecylindrical, forming an open spiral with a greater curvature in the posterior half. The cuticle is thick with fine, superficial striations. Eight or nine lateral body pores are present in the oesophageal region, 13 or 14 between the oesophagus and vulva and 21 or 22 between the vulva and anus (Siddiqi, 1974). The female has one or two ovaries, which are usually paired and reflexed, one reduced and extending anteriorly, the other posteriorly (Shurtleff \& Averre III, 2000). Reproduction is parthenogenetic and males are extremely rare. Their body shape is the same as that of the female (Siddiqi, 1974). Males 
have two opposed, outstretched testes and the spicules are strong with lateral guiding pieces (Siddiqi, 1979). Both males and females have short, dorsally rounded tails. The tail has a terminal peg situated ventrally and is 8 to $12 \mu \mathrm{m}$ long. This peg is a distinct characteristic of the species (Figure 1) (Luc \& Cohn, 1982).

Descriptions of this nematode are varied, for example; the listed length of females ranges from 2.8 to $3.4 \mathrm{~mm}$ and the odontostyle length vary from 120 to $144 \mathrm{~mm}$ (Thorne \& Allen, 1950; Lamberti et al., 1985; Barsi, 1989; Coiro et al., 1992). However, the soil environment might play a role in this variation since this factor is often ignored during collection (Prins, 1997). In 1977, Garau \& Prota described the four juvenile stages of $X$. index using three different measurements: body length, functional odontostyle length and replacement odontostyle length. The data varied considerably within each of these measurements, particularly across juvenile stages. Separation of the first and second stage juveniles was particularly difficult, but with any single measurement used, the third and fourth stages were readily identified with a high degree of accuracy (Garau \& Prota, 1977).

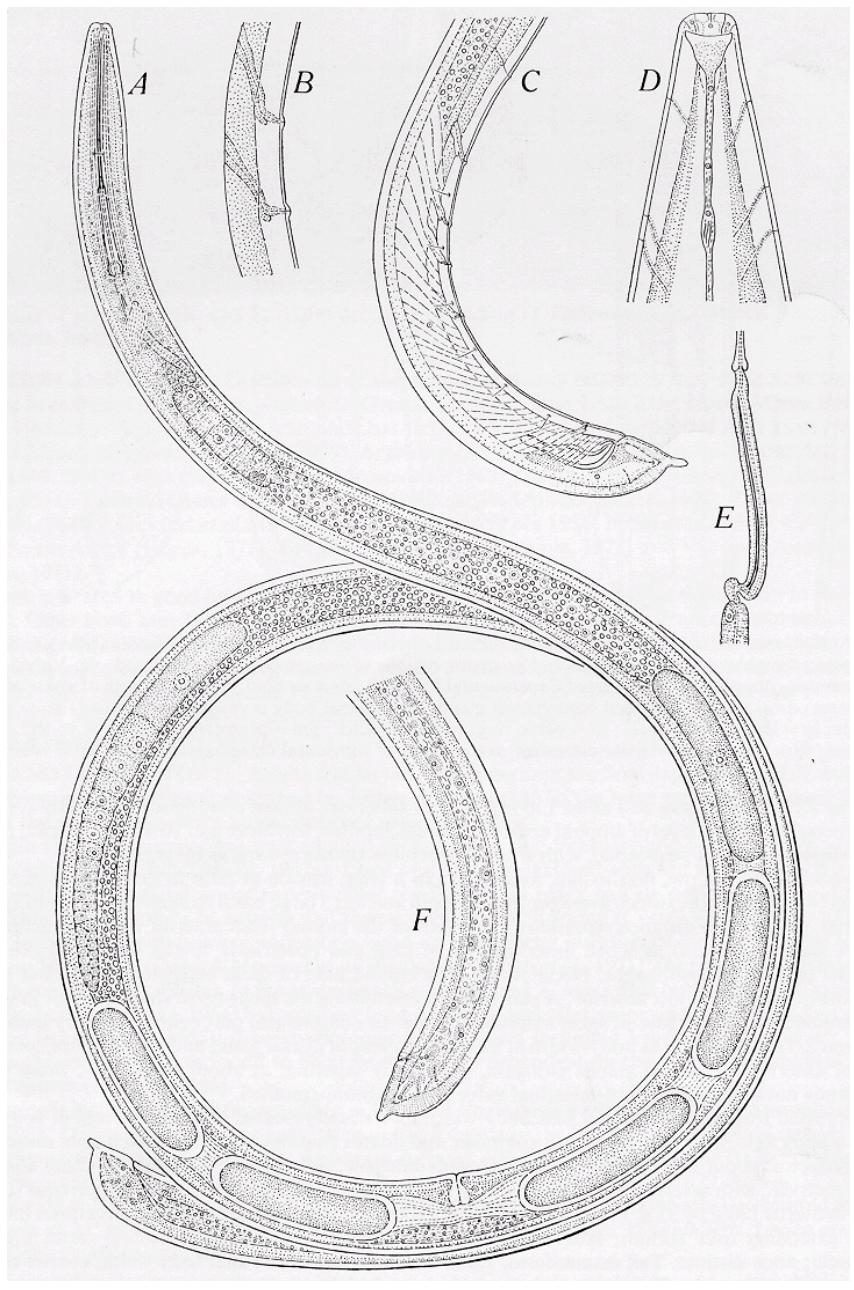

\section{FIGURE 1}

$X$. index as described by Thorne \& Allen, 1950. A: Female. B: Detail of supplements. C: Male posterior. D: Head end showing amphid. E. Replacement spear in anterior portion of oesophagus of larvae. F: Female posterior (Siddiqi, 1974).
It is important to be able to distinguish different species of Xiphinema from each other. Xiphinema index, $X$. diversicaudatum, $X$. vuittenezi and $X$. italiae are closely related taxonomically and therefore difficult to distinguish regarding morphological and morphometrical characteristics. This has led to efforts using PCR (Polymerase Chain Reaction) techniques and species-specific primers (Esmenjaud \& Bouquet, 2009) to distinguish between the species on molecular level. Specific ribosomal regions of the genome were sequenced in one population of each species and species-specific primers were developed from the sequencing data and allowed to identify single individuals at different developmental stages (Wang et al., 2002). The speciesspecificity of those primers for $X$. index, $X$. diversicaudatum and $X$. vuittenezi detection was then confirmed (Hübschen et al., 2004a) and have become a tool that facilitates taxonomic identification for non-specialists. Similarly, Hübschen et al. (2004b) developed species-specific ribosomal primers for seven Longidorid species of which some are also known as virus vectors. These Longidorid primers were tested for sensitivity and selectivity on closely related species and proven to be highly specific in detecting all developmental stages within a species, and also in distinguishing a single target nematode from a community (Hübschen et al., 2004b).

Range, habitat, biology and culturing of Xiphinema index Dagger nematodes are found in all soil types. In South Africa, 16 species of Xiphinema were found in soil samples analysed from five viticulture regions in the Cape Province and $X$. index was present in three of these regions (Malan $\&$ Meyer, 1994). The population of $X$. index decreases with soil depth. More than $92 \%$ of all nematodes are found in the 0 to $300 \mathrm{~mm}$ zone where most vine roots occur (De Klerk \& Loubser, 1988). Earlier research done in California, showed that $X$. index could be found as deep as $360 \mathrm{~cm}$ (Raski et al., 1965a) and are likely to be found wherever roots are. In France, the highest number of individuals occurred at 40$110 \mathrm{~cm}$ depth, corresponding to the layers where the highest densities of fine roots were observed in both Champagne (Esmenjaud et al., 1992) and Bordeaux (Villate et al., 2009) vineyards. Light to medium textured soils with a $\mathrm{pH}$ between 6.5 and 7.5 seem to be preferred (Siddiqi, 1974). Based on a study done in a Barossa Valley vineyard in Australia, the best time to determine $X$. index densities was in the late spring (Quader et al., 2003).

Temperature is an important modulating factor on the reproduction and life cycle of $X$. index, which is typically associated with grapevines in warm climates. The $X$. index population increased more rapidly as the soil temperature increased from 16 to $28^{\circ} \mathrm{C}$. In Italy, it was found that $X$. index numbers are lower in winter (Coiro et al., 1987; Coiro et al., 1991), but a study in California found that the populations peaked in the winter (Feil et al., 1997) possibly due to more accurate sampling in moist soils. A study done in England under experimental conditions showed that $X$. index egglaying peaked during summer months, with maximum populations in autumn and lowest populations in spring (Siddiqi, 1974).

Xiphinema index has been shown to survive in a wide range of soil temperatures ranging from $-11^{\circ} \mathrm{C}$ to $35^{\circ} \mathrm{C}$, 
but constant temperatures for 10 days of $45^{\circ} \mathrm{C}$ or $-22^{\circ} \mathrm{C}$ killed the nematodes. Fluctuations in diurnal temperatures also lowered $X$. index survival rates (Cotten et al., 1971). Females typically produce an egg every 24 to 26 days when the temperature is above a minimum daily threshold of $10^{\circ} \mathrm{C}$. Eggs are laid singly in the soil close to the feeding site (Weischer \& Wyss, 1976) and the life cycle takes 3 to 5 months to complete at $28^{\circ} \mathrm{C}$, but slows down to 7 to 9 months at lower temperatures (Nicholas et al., 2007). Reproduction rate has been shown to be highest at $29.4^{\circ} \mathrm{C}$ (Siddiqi, 1974). As mentioned, reproduction is by parthenogenesis (Dalmasso, 1975) and a single larva is capable of generating a population. Eggs hatch in 6 to 8 days and the first molt takes place outside the egg 24 to 48 hours after hatching. Dagger nematodes have four juvenile stages; the $2^{\text {nd }}, 3^{\text {rd }}$ and $4^{\text {th }}$ molts occur at six-day intervals (Siddiqi, 1974). The nematode reproduces by meiotic parthenogenesis (Dalmasso, 1975) but sexual reproduction has been observed from a recent field population genetics study (Villate et al., 2009) even though it appears to be a rare event. Thus, increasing genetic diversity through sexual recombination in $X$. index, involving the rare male has been observed, does exist and explains the occasional detection of females having spermatozoa in the uterus (Luc \& Cohn, 1982). Initial studies found that the $X$. index genome consisted of 20 chromosomes and suggested that it might be a tetraploid (Dalmasso \& Younes, 1969), but it was later reported that the genome consisted of 10 chromosomes (Dalmasso, 1975).

Earlier studies showed substantial variations in reproduction rates and life cycle stages under greenhouse conditions (Cohn \& Mordechai, 1970; Coiro et al., 1990); $X$. index reproduced faster in non-clay soils under these conditions (Coiro et al., 1987). Fine sand and sandy loam soils with a soil moisture content of 10 to $15 \%$ induced higher reproduction results than coarse sand (Sultan \& Ferris, 1991). In a Californian greenhouse study the cycle from egg to female has been reported to be 22 to 27 days (Pearson \& Goheen, 1988), whereas others report a 60-day life cycle (McKenry, 2000). Individuals can live for many years (Nicholas et al., 2007) as claimed by a French report of survival in stored soil for four years (Demangeat, et al., 2005). In a study done by Brown \& Coiro (1985), it was shown that the longevity of $X$. index on Ficus carica was 60 to 64 weeks, with a total reproductive capacity of 140 to 160 progeny. Longevities and reproductive capacities for female $X$. index from Italy and the U.S.A. were similar when raised on F. carica (Brown \& Coiro, 1985).

\section{Effect of Xiphinema index feeding on grapevines}

Xiphinema index feeding initially causes a swollen club-like gall on root tips, which varies in size with the size and vigor of the root. The feeding wound then becomes reddish brown to black and forms slightly sunken lesions on the roots (Wyss, 1978). Infested root systems are stunted and have a witch's broom appearance after successive rounds of new roots branching and being damaged from behind the original damaged root tip (Pearson \& Goheen, 1988). Extensive root damage eventually results in reduced shoot growth and yield. Common symptoms of $X$. index feeding are plant stunting, chlorosis, root swellings or galls and root necrosis (Figure 2)
(Wyss et al., 1980). The number of galls formed has been correlated with the size of a nematode population and with size of the root system in potted plants (Xu et al., 2008). The clubbed galls suggest that the nematodes discharge some substance into the roots to induce swelling (O'Bannon \& Inserra, 1990) and this galling has been shown to occur as early as 24 hours after feeding (Fisher \& Raski, 1967).

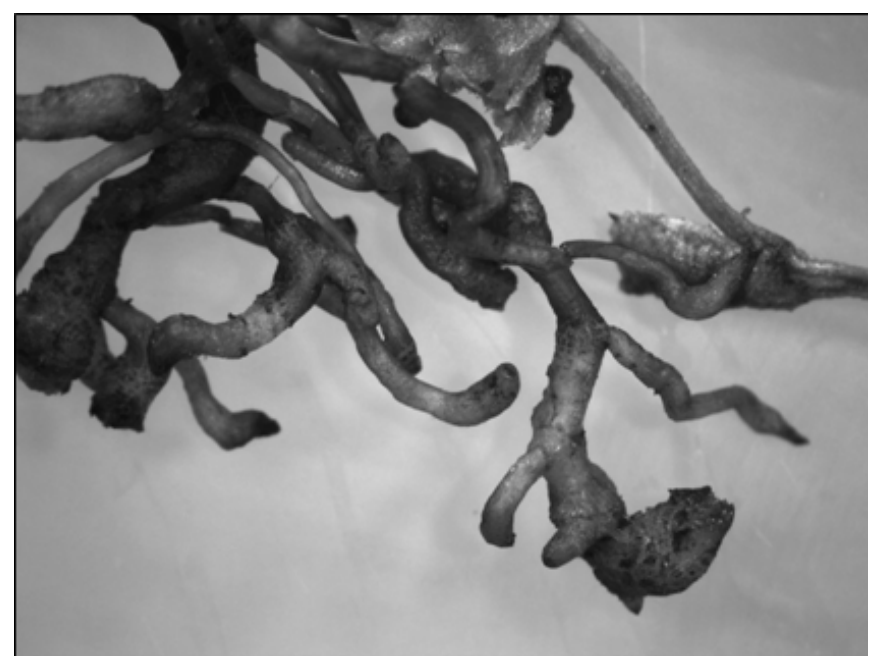

FIGURE 2

Feeding damage (galling) caused by $X$. index on roots of St. George, a highly susceptible variety.

Nematode feeding damage induces water and nutrient stress, which in turn reduces vine vigor and yield. Penetration of roots by nematode stylet also makes them more susceptible to root-rotting fungi (Nicholas et al., 2007), which contributes to vine death.

The foliage symptoms caused by root damage from $X$. index feeding are similar to those caused by root rots, drought and other root-feeding pests. Soil conditions can also restrict root growth and consequently, damage done by $X$. index can be made worse. These conditions include drought, compact soils, shallow water tables, saline soils and highly acidic or alkaline soils. In addition, it is common to have more than one type of nematode attacking the roots, which often intensifies the damage (Nicholas et al., 2007).

The combined effect of $X$. index feeding and its association with GFLV may kill grapevines (Nicholas et al., 2007). Cultural practices, such as girdling, which put grapevines under stress, can further intensify the deleterious effects of nematode feeding (Raski, 1955). If soil and cultural conditions are favorable, infested grapevines are able to better tolerate the presence of nematodes (Anwar et al., 2003).

All stages, including adult females, move through the soil to find and feed on roots (Nicholas et al., 2007). Xiphinema index prefers to feed near the root tips (Weischer \& Wyss, 1976) by inserting their mouth parts (stylets) into the root tissue (Figure 3) (De Klerk \& Loubser, 1988). This nematode perforates 5 to 7 cells deep with a twisting action of the odontostyle, followed by rhythmical contractions of the oesophageal bulb and feeding actions (Weischer \& Wyss, 1976; Taylor \& Brown, 1997). 
The time that $X$. index stay at one feeding site can vary from several minutes to several days. Root areas already fed on, attract more nematodes and can result in crowding (Weischer \& Wyss, 1976).

\section{Non-grape hosts}

Xiphinema index has been reported to attack figs, roses and citrus (Nicholas et al., 2007). In Italy, X. index was also found on the roots of mulberry trees (Siddiqi, 1974). Xiphinema species in general are associated with root damage on ornamental shrubs, corn, lawn grasses, oats, roses, pines, peanuts (Garrett et al., 1966), as well as pistachio (Weiner \& Raski, 1966). Coiro \& Serino (1991) reported that $X$. index reproduction could occur on petunia and tomato, which render them hosts. A lesser extent of reproduction was found on Chenopodium amaranticolour and tobacco plants, showing that some herbaceous plants may be suitable as bait plants, but differences in host status are likely between different $X$. index populations (Coiro \& Serino, 1991). Brown \& Coiro (1985) reported that $F$. carica can be a more suitable host for $X$. index than $V$. vinifera under controlled greenhouse conditions. They found that Olea europaea, Citrus aurantium and four tomato cultivars were poor hosts (Brown \& Coiro, 1985).

\section{In vitro culture}

No quick method exists to screen grapevines for $X$. index resistance. In vitro dual culture on grape roots might overcome this problem. For in vitro culture to be successful,

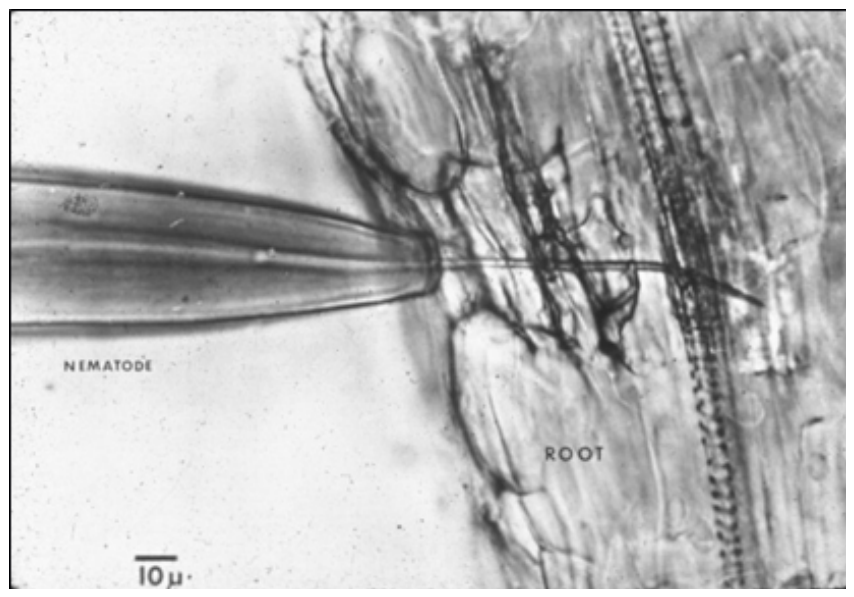

FIGURE 3

Nematode feeding on grapevine roots (Wylie et al., 2004). nematodes have to be surface sterilised. In 1978, Wyss successfully surface sterilised $X$. index using a $0.03 \% \mathrm{NaN}_{3}$ solution. The nematodes were transferred to a $0.6 \%$ agar media where they were left to feed on fig roots. In 1983, Bleve-Zacheo \& Zacheo did a similar study, but they used a $2 \%$ agar media. In both these studies, $X$. index were alive and feeding on fig roots within a few days. They observed reproduction and growth of juveniles in vitro. However, a study done by Bavaresco \& Walker (1994) on different sterilisation methods showed that no nematodes survived the $\mathrm{NaN}_{3}$ treatment. The only surface sterilisation treatment $X$. index survived was a Sigma A-7292 antibiotic antimycotic compound. After this treatment root tip swelling and egg production were observed after 50 days and first stage larvae were observed after 60 days (Bavaresco \& Walker, 1994).

\section{Extraction methods}

Nematodes can be extracted from plants and soil in several ways. Soil samples are usually taken near the vine up to a depth of $600 \mathrm{~mm}$ (Quader et al., 2003) and the method of extraction is usually dependent on the nematode species (Brown \& Boag, 1988) and soil type (Viglierchio \& Schmitt, 1983). Brown and Boag (1988) showed that care should be taken when handling soil samples containing virus vector nematodes. It was shown that $X$. index were more susceptible to rough handling than some Longidorus species, and that dropping soil samples can kill nematodes (Brown \& Boag, 1988). Four different methods for nematode extraction are summarised in Table 1.

\section{Xiphinema index as a vector of grapevine fanleaf virus} Grapevine fanleaf virus is a member of the nepovirus (nematode vectored polyhedral particle shape) group (Pearson \& Goheen, 1988). This group contains 37 viral species that have isometric particles of about $28 \mathrm{~nm}$ in diameter. One-third of the viruses in this group are known to be transmitted by nematodes (Taylor \& Brown, 1997).

\section{Genetics}

Nepoviruses are positive-sense single-stranded RNA viruses, and have two genomic RNA's. The larger one is referred to as RNA1 and the smaller as RNA2. The large RNA1 molecule carries the genetic determinants for host-range, seed transmissibility and some types of symptom expression, while the small RNA2 molecule contains genes for the coat protein, nematode transmissibility and some symptom expression (Taylor \& Brown, 1997). Full-length cDNA

TABLE 1

Nematode extraction methods (Viglierchio \& Schmitt, 1983; Evans et al., 1993; Shurtleff \& Averre III, 2000).

\begin{tabular}{lll}
\hline Method & \multicolumn{1}{c}{ Advantage } & Disadvantage \\
\hline Cobb's sieving and gravity & - Rapid method & - Samples not always clean \\
method & - Larger soil samples used & - Egg and juveniles not retained \\
Baermann funnel method & - Active adult and juveniles extracted & - Time consuming: \\
& - Used in combination with first method & - hours to days \\
& - Limits soil and root debris & - depending on sample size temperature and species \\
Mist extraction method & - No anaerobic conditions & - Anaerobic conditions in funnels \\
Centrifugal flotation method & - Active and sedentary nematodes recovered & - High mortality rate for $X$. index \\
\end{tabular}


clones of GFLV RNA1 and RNA2 have been constructed for the synthesis of infectious transcripts (Viry et al., 1993).

The determinants responsible for the specific spread of GFLV by $X$. index are located within the 513 C-terminal residues of the polyprotein encoded by RNA2. Findings suggest that the coat protein provides the basic determinants for the specificity of GFLV transmission by $X$. index (Belin et al., 2001). In 2004 it was confirmed that the viral coat protein was the key determinant for GFLV transmission of GFLV (Andret-Link et al., 2004a). Genetic variability exists within the RNA2 molecule of GFLV (Pompe-Novak et al., 2007). Multiple interspecies recombination events were identified within the RNA2 molecule of strains from GFLV and the arabis mosaic virus (Vigne et al., 2008).

GFLV can be inoculated by grafting so that the impact of virus resistance can be studied without the impact of nematode feeding or transmission. Approach grafting techniques were used to study GFLV resistance in $V$. vinifera (Walker \& Meredith, 1989). Bouquet (1981) also used graft transmission to examine resistance in Vitis species. Valat et al. (2000) developed a biolistic method to inoculate Vitis species with GFLV to enable the examination of GLFV genetics and resistance on a molecular level. However, consistent detection of the virus in grapevine tissue after bombardment was not successful. The transmission and infectivity of GFLV might also vary among virus strains (Valat et al., 2003). Fattouch et al. (2005) detected and characterised two different strains of GFLV in Tunisia. Different grapevine samples were subjected to ELISA (enzyme-linked immunosorbent assay) techniques and then amplified by using RT-PCR (Reverse Transcription Polymerase Chain Reaction). The PCR products were used for RFLP (Restriction Fragment Length Polymorphism) analysis and data showed a clear distinction between two GFLV strains. This study was the first report to show molecular variability of GFLV (Fattouch et al., 2005).

\section{Symptoms}

Grapevine fanleaf virus is one of the oldest viruses of $V$. vinifera (Pearson \& Goheen, 1988) and is still one of the most economically impacting pathogens (Vigne et al., 2005). Records of this disease date back 200 years and it is believed that GFLV may have existed in the Mediterranean Basin and the Near East since the earliest cultivation of grapes (Pearson \& Goheen, 1988).
A

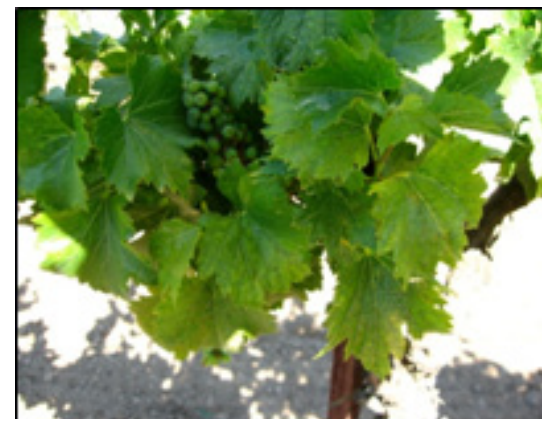

$\mathrm{B}$

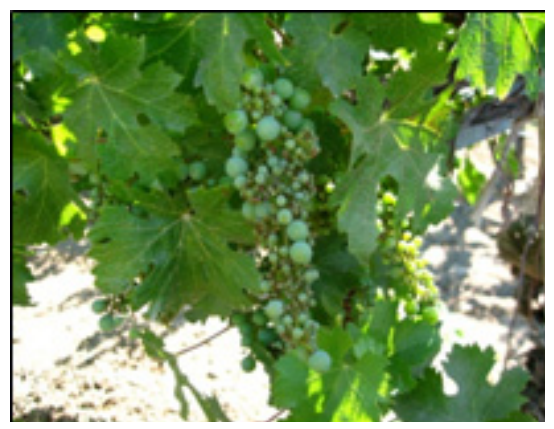

C

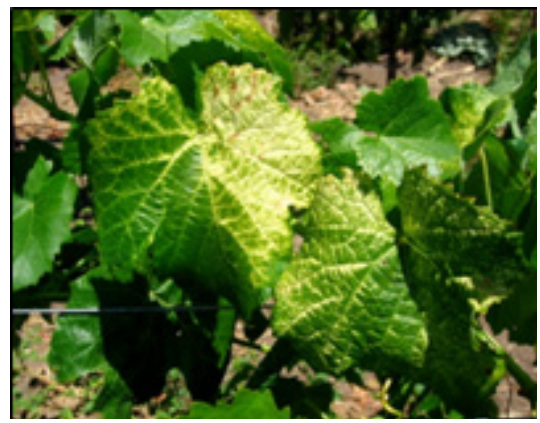

FIGURE 4

\section{Diagnosis and detection}

Grapevine fanleaf virus is one of a number of viruses for which woody indexing is used to verify virus-free status. The rootstock variety St. George is the standard indicator for the presence of GFLV, but symptoms are common on most $V$. vinifera varieties. Woody indexing involves grafting

Vines infected with GFLV are generally seen in patches et al. 1992). In 1954 Hewitt documented the symptoms ar the use of indicator plants for GFLV. The impact of GFLV varies with the tolerance of the cultivar and more tolerant 1988).

The disease is characterised by four distinct symptoms:

Infected leaves exhibit widely open petiolar sinuses and abnormally gathered primary veins causing a -like shape (Figure 4A). This leaf deformity gave the name of the virus (Pearson \& Goheen, 1988). Leaf and shoot deformities develop early shoots can also be malformed, showing abnorma branching, double nodes, short internodes and zigzag growth (Raski et al., 1983).

- Yellow mosaic develops on leaves of affected vines in early spring. Specks vary from a few scattere resumes its normal colour (Pearson \& Goheen, 1988).

- Bunches are fewer and smaller than usual with shot (Figure 4B) (Pearson \& Goheen, 1988). The GFLV can cause up to $80 \%$ with herbicide damage and mite injury (Nicholas et al., 2007).

- Affected vines show yellow vein banding along the main veins of mature leaves. These symptoms are leaves show little malformation (Pearson Goheen, 1988). This symptom has been shown to be the result of cross infection with yellow speckle viroid (Szychowski et al., 1995). 
a candidate plant bud onto the highly reactive indicator variety. This index requires at least 18 months for reliable assays with grapevine viruses (Alley, 1955).

To accelerate the time required for detection of GFLV infection, serological techniques such as ELISA were developed (Rowhani, 1992). However, immunoassays are much less sensitive than techniques based on nucleic acid hybridisations (Fuchs et al., 1991) and PCR. Both RT-PCR (Fattouch et al., 2001) and immunocapture (IC)-RT-PCR (Acheche et al., 1999) have been shown to be successful as very sensitive GFLV detection methods.

In 2001, Fattouch et al. developed a RNA oligoprobe capture technique to detect GFLV in grapevine tissue. This procedure was compared to an IC technique using commercial antibodies. Grapevine fanleaf virus isolates from vineyards in northern Tunisia showed negative results with IC-RT-PCR, but were detected by the RNA oligoprobe capture technique (Fattouch et al., 2001). Detection of GFLV in the vector nematode firstly relied on ELISA (Bouquet, 1981; Esmenjaud et al., 1992; 1993) and then on RT-PCR, a method that allowed GFLV detection from a single viruliferous nematode as soon as 1994 (Esmenjaud et al., 1994). The RT-PCR was then refined (Demangeat et al., 2004) using a bead mill to disrupt the nematode and amplifying 555-bp fragment of the coat protein gene with two primers designed from conserved sequences. Styl RFLP analysis on the coat protein amplicon is used in addition to RT-PCR to enable the GFLV isolate carried by a single nematode to be characterised (Demangeat et al., 2004).

Significant progress has been made on the elucidation of the functions of most GFLV proteins, specifically those involved in the virus multiplication cycle, RNA replication, cell-to-cell movement and transmission by $X$. index. New insights into the genomic variability among isolates from naturally infected vineyards have also been made (AndretLink et al., 2004b).

\section{Acquisition and transmission}

In 1958, Hewitt et al. showed that $X$. index is the natural vector of the GFLV and that GFLV is soil-borne and not air-borne. This study was also the first to prove that nematodes are able to vector soil-borne viruses and that spread is typically slow and in a concentric pattern (Hewitt et al., 1958).

Laboratory methods for assessing the transmission of nepoviruses were established by Trudgill et al. (1983). Nematode vectors that feed on plant roots can transmit viruses in all development stages, but GFLV is lost with each molt and needs to be reacquired (Taylor \& Raski, 1964). However, GFLV is not passed through nematode eggs (Taylor \& Raski, 1964; McFarlane et al., 2002). Xiphinema index has the ability to ingest GFLV particles from an infected grapevine, retain the virions at specific retention sites within its feeding apparatus and subsequently infect a recipient vine when feeding (Andret-Link et al., 2004b). The virus also occurs in grapevine pollen (Cory \& Hewitt, 1968), but not in seeds (Shurtleff \& Averre III, 2000).

The virus is acquired by $X$. index, feeding first on the roots of an infected vine and then transferring the virus by feeding on healthy vines (Leavitt, 2000). A single brief feeding on an infected vine root can make nematodes viruliferous.
The nematode can retain the virus for up to eight months in the absence of host plants or up to three months when feeding on resistant host plants (Taylor \& Raski, 1964). When nematodes were stored in soil (and thus starved) under controlled conditions, the virus was detected for up to four years in nematode samples of 20 adult individuals (Demangeat et al., 2005). The minimum GFLV acquisition threshold for transmission from $X$. index to the grapevine was established by Alfaro \& Goheen (1974), and proved to be five minutes. The virus has no measurable effect on the rate of reproduction of its vector, but improved its survival rate during starvation (Das \& Raski, 1969).

In laboratory and greenhouse studies, temperature, soil moisture, the host plant, the population and developmental stages of the nematode and even the size of the pot affected the rate of virus transmission. In general, increasing the acquisition and transmission access periods from hours to several weeks increased the frequency of transmission (Shurtleff \& Averre III, 2000). The virus is acquired and transmitted with an access time of 5 to 15 minutes in a soil temperature of 13 to $24^{\circ} \mathrm{C}$ (Siddiqi, 1974). Even when $X$. index does not carry the virus, roots are still damaged (McKenry, 1992). The nematodes retain the ability to transmit the virus for 4 to 8 weeks when feeding on nonviruliferous plants (Taylor \& Raski, 1964) and for up to nine months under starvation conditions (Raski \& Hewitt, 1960). Successful virus transmission requires that infective virus particles be inoculated into plant cells that are healthy and undamaged (O’Bannon \& Inserra, 1990).

\section{Vector method, spread and specificity}

According to Pearson \& Goheen (1988), GFLV's natural host range is limited to Vitis species. Recent studies showed that Bermuda grass in Iran is infected with GFLV. The virus was detected by RT-PCR using two different pairs of GFLV specific primers and ELISA. However, the Bermuda grass expressed few or no symptoms of GFLV infection (Izadpanah et al., 2003). In addition to $X$. index, $X$. italiae has been reported to spread GFLV (Cohn et al., 1970), but these results were not corroborated (Esmenjaud \& Bouquet, 2009). Long-range spread of the GFLV is limited to the spread of infected plant material. Short-range spread depends on nematodes (Pearson \& Goheen, 1988).

The transmission process is characterised by a high degree of specificity between GFLV and $X$. index. Viruses are attached to the cuticular lining and the lumen of the odontophore and the pharynx. They are shed with the cuticle when the nematode molts (Taylor \& Robertson, 1970). During feeding, virus particles dissociate from the cuticular lining at the retention site and are carried by the saliva of the nematode to the grapevine plant cells. Dissociation of the virus particles occurs when saliva passes through the lumen of the oesophagus and absorbs the virus at the retention site. Virus particles are released into the grapevine cells during the initial feeding phases (O'Bannon \& Inserra, 1990). Limited information is available on the mechanisms of the transmission process of GFLV (Belin et al., 2001). 
Management strategies for Xiphinema index and grapevine fanleaf virus

Each disease and pest requires a different control strategy. For example, foliar diseases of grapes need specific weather patterns. Some diseases and pests spread quickly, others slowly and viruses live within the vine. Nematodes are primarily spread by the movement of contaminated soil or infested plant material (Nicolas et al., 2007). Preventative measures for controlling $X$. index and GFLV are usually the best (Hewitt, 1954), but not always practical given high grower demand for specific clones of varieties that might also be infected with fanleaf. It is advisable to plant only certified planting stock (Golino, 1993), but studies have shown that even healthy grapevines can become infected with GFLV transmitted by $X$. index from the soil within three years after planting (Hewitt et al., 1962).

\section{Grapevine rootstocks}

The use of resistant rootstocks upon which fruiting cultivars are grafted is often the best way to overcome nematode problems in perennial crops. Rootstocks for use against the $X$. index / GFLV disease complex must resist both the nematode and virus. However, resistance to both does not exist within commonly used commercial rootstocks (Meredith et al., 1982; Harris, 1983). The 110R rootstock, which is often used in South Africa for its phylloxera resistance and good vigor, is susceptible to $X$. index feeding. However, Harmony, Freedom, 3309C and Schwarzmann had some degree of resistance (Harris, 1983; Malan \& Meyer, 1993). More rootstock examples are named and described in Table 2 in terms of their resistance or susceptibility towards $X$. index feeding.

\section{Hot water treatment, heat therapy and somatic embryogenesis}

A common means of spreading $X$. index is by the distribution of infested dormant rootings or bench grafts from nurseries or from vineyards where rootstocks are planted between rows in infested areas and then later moved to other areas. A hot water $\left(52^{\circ} \mathrm{C}\right)$ agitated soak for five minutes is recommended for treatment of infested materials (Nicholas et al., 2007). However, to avoid damaging roots or buds, accurate temperature control is essential and low numbers of nematodes may survive (Raski et al., 1965b).

Grape viruses are widely spread and controlling the distribution of infected plant materials was the genesis of clean stock/certification programs in the world's grape growing regions. Infected plants can be freed of viruses by heat therapy and/or meristem culture (Torres-Viñals et al., 2004). Meristem culture is effective in eliminating phloemlimited viruses, while heat therapy is normally required for viruses that readily invade plant meristems such as nepoviruses (Gambino et al., 2009). Buds from a candidate vine of unknown virus status can be grafted onto a nurse plant and heat-treated in a growth chamber at $37^{\circ} \mathrm{C}$ for two to three months. After this treatment, the buds are forced to grow and the resulting shoots are checked for the presence of virus by indexing or PCR-based testing. Heat therapy works because RNA based viruses degrade at high temperature and are eliminated before plant cells can be damaged. The process is not highly efficient, but was widely used in the past (Gifford \& Hewitt, 1961). Alternatively, a small segment, less than one $\mathrm{mm}$, of the shoot tip can be excised and grown in sterile culture. In many cases this small piece of tissue has escaped virus infection and can be grown into a new plant (Barlass \& Skene 1978) which can be verified free of virus by indexing and PCR testing. In some cases these two techniques can be combined but in most cases meristem culture is effective (Gambino et al., 2009).

Somatic embryogenesis has also been used to efficiently eliminate several phloem-limited viruses from grapevine material (Goussard et al., 1991). By using this technique, GFLV was eliminated from grapevine tissue in combination with heat therapy of the explants (Goussard \& Wiid, 1992). In a study done by Gambino et al. (2009), it was possible to eliminate GFLV from plantlets by using somatic embryogenesis without using heat therapy with a success rate close to $100 \%$. The virus was however detected in all tested anthers and ovaries by using RT-PCR techniques, but not in the regenerated plantlets two years after transfer to greenhouse conditions (Gambino et al., 2009).

\section{Crop rotation and fallow periods}

Before vineyards are replanted with grapevines, the land

TABLE 2

Description of rootstock characteristics in terms of $X$. index resistance with $\mathrm{S}=$ susceptible, $\mathrm{R}=$ resistant and $\mathrm{MR}=$ moderately resistant.

\begin{tabular}{|c|c|c|c|}
\hline Rootstock & Genetic origin & Resistance & Reference \\
\hline $110 \mathrm{R}$ & V. berlandieri $\mathrm{x} V$. rupestris & $\mathrm{S}$ & Malan \& Meyer (1993) \\
\hline Harmony & (V. longii $\times$ Othello) $\mathrm{x}$ Dog Ridge & $\mathrm{R}$ & Harris (1983) \\
\hline Freedom & (V. longii $\mathrm{x}$ Othello) $\mathrm{x}$ Dog Ridge & $\mathrm{R}$ & Harris (1983) \\
\hline 3309C & $V$. rupestris $\mathrm{x} V$. riparia & $\mathrm{S}$ & McKenry et al. (2004) \\
\hline Schwarzmann & V. riparia & MR & Harris (1983) \\
\hline O39-16 & $V$. vinifera $\mathrm{x} M$. rotundifolia & $\mathrm{R}$ & McKenry et al. (2004) \\
\hline Ramsey & V. champinii & $\mathrm{S}$ & Ambrosi et al. (1966) \\
\hline Dog Ridge & $V$. rupestris $\mathrm{x} V$. candicans & $\mathrm{S}$ & Ambrosi et al. (1966) \\
\hline Fairy & Not known & MR & Ambrosi et al. (1966) \\
\hline Jacquez & $V$. aestivalis $\mathrm{x} V$. cinerea $\mathrm{x} V$. vinifera & $\mathrm{S}$ & Ambrosi et al. (1966) \\
\hline 775 Paulsen & $V$. berlandieri $\mathrm{x} V$. rupestris & $\mathrm{S}$ & Ambrosi et al. (1966) \\
\hline
\end{tabular}


can be cropped with cereals or grains to suppress grapevineattacking nematodes. Some crops can increase nematode populations, as is the case with growing pumpkins or tomatoes before replanting grapevines (Nicholas et al., 2007). An early study done by Raski (1955) suggested that three years is an adequate period for crop rotation. However, more recent studies suggest that $X$. index infested sites should be left fallow or rotated to crops other than grapes or figs for at least 10 years (McKenry, 2000). In moist sterile soil without food, $X$. index died after 9 to 10 months, but survived for 4 to 5 years in soil where grapevines were removed, but roots remained (Raski et al., 1965a). Since vine roots decay very slowly and act as a reservoir for $X$. index, it is beneficial (but not necessarily economically viable) to wait at least six to ten years before replanting (Golino et al., 1992). It must also be kept in mind that GFLV can still be detected in nematodes kept in soil without roots for four years (Demangeat et al., 2005).

\section{Nematicides}

Soil may be fumigated before planting, although such treatments rarely penetrate to depths greater than one meter and thus do not eradicate nematodes on deep perennial root systems (Lear et al., 1981). This is especially true for California where the soils are often deep and finestructured (Raski et al., 1983). Broad-spectrum fumigants are expensive, but they also kill soil insects, fungi and weeds as well as beneficial organisms. Before nematicides and fumigants can be applied, soil must be ripped and cleared of as many old roots as possible and dried to as great a depth as possible (Nicholas et al., 2007).

Non-fumigant nematicides can be applied to established vineyards by using soil drenches or applied through the drip irrigation system. These nematicides must be applied with care, as they are toxic to humans and may leave residues in or on fruit (Nicholas et al., 2007). Due to the high toxicity levels of nematicides and because they are unsafe for the environment and human health, their use is being highly restricted in the vineyards of the world (Bouquet et al., 2000).

\section{Breeding Xiphinema index and grapevine fanleaf virus resistant vines}

Breeding fanleaf degeneration resistant grape rootstocks would be a logical step in the process of controlling this disease, however as with all perennial crops, the process can be slow and difficult (Esmenjaud \& Bouquet, 2009). Resistance to GFLV has been identified in Muscadinia rotundifolia (Boubals \& Pistre 1978; Walker \& Jin, 2000) and in some Middle Eastern $V$. vinifera cultivars (Walker et $a l ., 1985)$, although the latter sources have not been studied further.

Resistance to $X$. index has been found in a number of Vitis species, notably $V$. arizonica, $V$. candicans, $V$. rufotomentosa, V. solonis (Kunde et al., 1968) and M. rotundifolia (Bouquet et al., 2000). During a breeding program at the University of California, Davis found that two $V$. vinifera $\mathrm{x} M$. rotundifolia (VR) hybrids, O39-16 and O43-43, were highly resistant to $X$. index and prevented fanleaf degeneration. These two rootstocks were patented and released (Walker et al., 1991), although the recommendation for O43-43 was subsequently withdrawn due to insufficient phylloxera resistance (Walker $e t$ al., 1994). Once these rootstocks were used in field situations it became clear that although they had strong resistance to $X$. index feeding, they did not prevent the vectoring of GFLV as $X$. index probed for feeding sites. However, although scions grafted on these rootstocks became infected with GFLV, disease was not expressed (Walker et al., 1994; Walker \& Wolpert, 1994). Unfortunately these hybrids cannot be used as parents in future crosses due to sterility from the incomplete pairing of chromosomes resulting from a Vitis $(2 \mathrm{n}=38)$ x Muscadinia $(2 \mathrm{n}=40)$ cross (Walker et al., 1994). In France a nematode-resistant accession, obtained from a Vitis $x$ Muscadinia F1 hybrid (VRH8771) backcrossed to a Vitis rootstock, was patented in 2011 and is being released as the new rootstock 'Nemadex AB'. In the vineyard, it highly delays GFLV infection (Esmenjaud \& Bouquet, 2009), but the durability of its resistance to $X$. index over years will be challenged under controlled conditions (Esmenjaud et al., 2010).

The need for a broader range of rootstocks with strong resistance to fanleaf degeneration continues and efforts to discover strong sources of $X$. index resistance have built on the work of Kunde et al. (1968) mentioned above. Coiro et al. (1985) found that $V$. riparia and hybrids containing $V$. riparia also had degrees of resistance. Muscadinia species have also been studied to determine their $X$. index resistance and consequently their resistance to the vectoring of GFLV. Xiphinema index was found to attack Muscadinia roots very reluctantly and the few feeding sites that developed rapidly became necrotic indicating a hypersensitivity. Apparently this reaction prevented viruses from being transmitted, suggesting that these species are resistant to $X$. index feeding and the transmission of GFLV (Staudt \& Weischer, 1992). The basis for GFLV resistance in grapevines is not yet fully understood and need further investigation.

\section{Inheritance and mapping of DNA markers for resistance to Xiphinema index}

The highly heterozygous nature of grapevine limits the study of its genetics, but has been an advantage for breeding, which has led to a long history of breeding and domestication compared to other perennial crops (Myles et al., 2010). The publication of the first grapevine genome sequences (Jaillon, et al., 2007; Velasco et al., 2007) provided a new generation of molecular tools for grapevine breeding efforts. Doors were opened to identify genes responsible for agronomic traits and disease resistance as well as the assignment of biological functions to annotated sequences (Martínez-Zapater et al., 2009). Technologies such as QTLand linkage disequilibrium-based mapping are implemented to better understand the genetic structure of grapevines. Only a small portion of the genetic diversity of grapes has been explored. The grape genome sequence, in addition to rapidly developing technologies, will provide easier ways to improve existing grape cultivars while incorporating specific traits and disease resistance (Martínez-Zapater et al., 2009; Myles et al., 2010).

Since the 1970s at the University of California, Davis has been developing rootstocks to resist fanleaf degeneration. As 
part of this effort, $V$. rupestris $\mathrm{x} M$. rotundifolia hybrids were produced and 60 of 200 seedlings tested highly resistant to $X$. index feeding, several of which, including R8913-02 and R8913-21, were also resistant to the root-knot nematode and phylloxera. Genetic mapping efforts found that the RAPD (Random Amplified Polymorphic DNA) marker OPA-12 (Operon) was tightly linked to $X$. index resistance (Walker \& Jin, 1998). These $V$. rupestris x M. rotundifolia seedling populations were later found to be largely mistaken outcrosses of $V$. rupestris by forms of $V$. arizonica (Riaz et al., 2007). Two half siblings, R8909-15 x R8909-17 were used to create a mapping population 9621 , in which resistance to $X$. index segregated as a single dominant resistance gene. Initial mapping efforts used AFLP (Amplified Fragment Length Polymorphism) technology to identify over 500 segregating markers on 19 linkage groups (Walker \& Jin, 2000). This map was later used to position resistance to the bacterial causal agent of Pierce's disease, Xylella fastidiosa (Doucleff et al., 2004).

Previous work found that $V$. arizonica was resistant to $X$. index (Kunde et al., 1968) and suggested that resistance was inherited as a single heterozygous gene (Meredith et al., 1982). More recently, the 9621 population has been mapped with highly informative and co-dominant simple sequence repeat (SSR) markers further positioning resistance to $X$. fastidiosa and placing a major quantitative trait locus (QTL) for $X$. index resistance (XiRl) on chromosome 19 (Xu et al., 2008).

These studies as well as the agronomical importance of nematodes and the viruses they vector, prompt interest in determining the extent of $X$. index resistance in $V$. arizonica and whether other accessions had the same degree and genetics of resistance to this nematode pest.

\section{LITERATURE CITED}

Acheche, H., Fattouch, S., M'hirsi, S., Marzouki, N. \& Marrakchi, M. 1999. Use of optimised PCR methods for the detection of GLRaV3: a closterovirus associated with grapevine leafroll in Tunisian grapevine plants. Plant Mol. Biol. Rep. 17, 31-42.

Alfaro, A. \& Goheen, A.C., 1974. Transmission of strains of grapevine fanleaf virus by Xiphinema index. Plant Dis. Rep. 58, 549-552.

Alley, C.J., 1955. The certification of grapevines for adherence to variety and for freedom from disease. Am. J. Enol. Vitic. 6, 23-26.

Ambrosi, H., Coetzee, J.H.L., Van Niekerk, J. \& Kriel, G.J. le R., 1966. Comparison of rootstocks in South Africa. 1966 Survey. Stellenbosch Wine Institute. pp. 1-27.

Andret-Link, P., Schmitt-Keichinger, C., Demangeat, G., Komar, V. \& Fuchs, M., 2004a. The specific transmission of grapevine fanleaf virus by its nematode vector Xiphinema index is solely determined by the viral coat protein. Virology 320, 12-22.

Andret-Link, P., Laporte, C., Valat, L., Ritzenthaler, C., Demangeat, G., Vigne, E., Laval, V., Pfeiffer, P., Stussi-Garaud, C. \& Fuchs, M., 2004b. Grapevine fanleaf virus: Still a major threat to the grapevine industry. J. Plant. Pathol. 86, 183-195.

Anwar, S.A., McKenry, M.V., Youl, K.Y. \& Anderson, A.J., 2003. Induction of tolerance to rootknot nematode by Oxycom $\square$. J. Nematol. 35, 306-313.

Barlass, M. \& Skene, K.G.M., 1978. In vitro propagation of grapevine (Vitis vinifera L.) from fragmented shoot apices. Vitis 17, 335-340.
Barsi, L., 1989. The Longidoridae (Nematoda: Dorylaimida) in Yugoslavia. I. Nematol. Medit. 17, 97-108.

Bavaresco, L. \& Walker, M.A., 1994. Techniques for successfully establishing Xiphinema index in dual culture with grape. Am. J. Enol. Vitic. $45,273-277$

Belin, C., Schmitt, C., Demangeat, G., Komar, V., Pinck, L. \& Fuchs, M. 2001. Involvement of RNA2-encoded proteins in the specific transmission of grapevine fanleaf virus by its nematode vector Xiphinema index. Virology 291, 161-171.

Bleve-Zacheo, T. \& Zacheo, G., 1983. Early stage of disease in fig roots induced by Xiphinema index. Nematol. Medit. 11, 175-187.

Boubals, D. \& Pistre, R. 1978. Résistance de quelques Vitacées et des portegreffes usuels en viticulture au nématode Xiphinema index et à l'inoculation par le virus du court-noué (GFLV). 2ème Symposium International d'Amélioration de la Vigne. Paris (INRA Editions) 199-207.

Bouquet, A., 1981. Resistance to grape fanleaf virus in Muscadine grape inoculated with Xiphinema index. Plant Dis. 65, 791-793.

Bouquet, A., Danglot, Y., Torregrosa, L., Bongiovanni, M. \& CastagnoneSereno, P., 2000. Breeding rootstocks resistant to grape fanleaf virus spread, using Vitis x Muscadinia hybridization. Acta Hort. 528, 517-526.

Brown, D.J.F. \& Coiro, M.I., 1985. The reproductive capacity and longevity of Xiphinema index (Nematoda : Dorylaimida) from three populations on selected host plants. Rev. Nématol. 8, 171-173.

Brown, D.J.F. \& Boag, B., 1988. An examination of methods used to extract virus-vector nematodes (Nematoda: Longidoridae and Trichodoridae) from soil samples. Nematol. Medit. 16, 93-99.

Brown DJF, Dalmasso A, Trudgill DL. 1995. Nematode pests of soft fruits and vines. In Plant parasitic nematodes in temperate agriculture. Editor(s): K. Evans, D. L., Trudgill \& M. Webster J. M. CAB, Oxon, UK, pp. 427-462.

Cohn, E., \& Mordechai, M., 1970. The influence of some environmental and cultural conditions on rearing populations of Xiphinema and Longidorus. Nematologica 16, 85-93.

Cohn, E., Tanne, E. \& Nitzany, N.E., 1970. Xiphinema italiae, a new vector of grapevine fanleaf virus. Phytopathology 60, 181-182.

Coiro, M.I., Lamberti, F., Borgo, M. \& Egger, E., 1985. Reproduction of Xiphinema index on different grapevine rootstocks. Phytopath. Medit. 24, 177-179.

Coiro, M.I., Taylor, C.E. \& Lamberti, F., 1987. Population changes of Xiphinema index in relation to host plant, soil type and temperature in southern Italy. Nematol. Medit. 15, 173-181.

Coiro, M.I., Brown, D.J.F. \& Lamberti, F., 1990. Reproduction of Xiphinema index (Nematoda: Dorylaimida) on five plant species. Nematologica 36 , 474-478.

Coiro, M.I. \& Serino, M., 1991. Possible herbaceous hosts for Xiphinema index in virus transmission experiments. Nematol. Medit. 19, 251-252.

Coiro, M.I., Agostinelli, A. \& Lamberti, F., 1992. [Longidoridae (Nematoda) in the vineyards of the province of Verona.] I Longidoridae (Nematoda) nei vigneti della provincia di Verona. Nematol. Medit. 20, 87-95.

Cory, L. \& Hewitt, W.B., 1968. Some grapevine viruses in pollen and seeds. Phytopathology 58, 1316-1320.

Cotten, J., Flegg, J.J.M. \& Popham, A.M., 1971. Population studies with Xiphinema diversicaudatum and $X$. index maintained under two temperature regimes. Nematologica 16, 584-590.

Dalmasso, A. \& Younes, T., 1969. [Oogenesis and embryogenesis in Xiphinema index (Nematoda: Dorylaimida)] Ovogenese et embryogenese chez Xiphinema index (Nematoda: Dorylaimida). Ann. Zool. Ecol. Anim. $1,265-279$.

Dalmasso, A., 1975. Cytogenetics and reproduction in Xiphinema and Longidorus. In: Nematode vectors of plant viruses. F. Lamberti, C.E. Taylor \& J.W. Seinhorst (eds.). Plenum Press, New York. pp.139-151. 
Das, S. \& Raski, D.J., 1969. Effect of grapevine fanleaf virus on the reproduction and survival of its nematode vector, Xiphinema index Thorne \& Allen. J. Nematol. 1, 107-110.

Decraemer, W. \& Geraert, E., 2006. Ectoparasitic nematodes. In: Plant Nematology. R.N. Perry \& M. Moens (eds.). Biddles Ltd, King’s Lynn, UK. pp. 153-184

De Klerk, C.A. \& Loubser, J.T., 1988. Relationship between grapevine roots and soil-borne pests. In: The grapevine root and its environment. J.L. van Zyl, (ed.). South African Department of Agriculture and Water Supply. pp. 88-105.

Demangeat, G., Komar, V., Cornuet, P., Esmenjaut, D. \& Fuchs, M., 2004. Sensitive and reliable detection of grapevine fanleaf virus in a single Xiphinema index vector. J. Virol. Meth. 112, 79-86.

Demangeat, G., Voisin, R., Minot, J.C., Bosselut, N., Fuchs, M. \& Esmenjaud, D., 2005. Survival of Xiphinema index in vineyard soil and retention of grapevine fanleaf virus over extended time in the absence of host plants. Phytopathology 95, 1151-1156.

Doucleff, M., Jin, Y., Gao, F., Riaz, S., Krivanek, A.F. \& Walker, M.A., 2004. A genetic linkage map of grape, utilizing Vitis rupestris and Vitis arizonica. Theor. Appl. Gen. 109, 1178-1187.

Esmenjaud, D., Walter, B., Valentin, G., Guo, Z. T., and Cluzeau, D., 1992. Vertical distribution and infectious potential of Xiphinema index (Thorne et Allen, 1950) (Nematoda: Longidoridae) in fields affected by grapevine fanleaf virus in vineyards in the Champagne region of France. Agronomie $12,395-399$

Esmenjaud, D., Walter, B., Minot J. C., Voisin, R., \& Cornuet, P., 1993. Biotin-avidin ELISA detection of grapevine fanleaf virus in the vector nematode Xiphinema index. Journal of Nematology 25:401-405.

Esmenjaud, D., Pinck, L., Walter, B., and Abad, P., 1994. Detection of a region of the coat protein gene of grapevine fanleaf virus by RT-PCR in the nematode vector Xiphinema index. Plant Disease 78:1087-1090.

Esmenjaud, D. \& Bouquet, A., 2009. Selection and application of resistant germplasm for grapevine nematodes management. In: Integrated management of fruit crops and forest nematodes. A. Ciancio \& K.G. Mukerji, (eds.). Springer Science+Business Media B.V. pp. 195-214.

Esmenjaud, D., Van Ghelder, C., Voisin, R., Bordenave, L., Decroocq, S., Bouquet, A. and Ollat, N., 2010. Host suitability of Vitis and VitisMuscadinia material to the nematode Xiphinema index over 1 to 4 years. Am. J. Enol. Vitic. 61, 96-101.

Evans, K., Trudgill, D.L. \& Webster, J.M., (eds.) 1993. Plant parasitic nematodes in temperate agriculture. CAB International, Wallingford, Oxon, U.K.

Fattouch. S., M'hirsi, S., Acheche, H., Marrakchi, M. \& Marzouki, N., 2001. RNA Oligoprobe capture RT-PCR, a sensitive method for the detection of grapevine fanleaf virus in Tunisian grapevines. Plant Mol. Biol. Rep. 19, $235-244$.

Fattouch, S., Acheche, H., M'hirsi, S., Marrakchi, M. \& Marzouki, N., 2005. Detection and characterization of two strains of grapevine fanleaf nepovirus in Tunisia. Bulletin OEPP/EPPO 35, 265-270.

Feil, H., Westerdahl, B.B., Verdegaal, P. \& Smith, R., 1997. Effects of seasonal and site factors on Xiphinema index populations in two California vineyards. J. Nematol. 29, 491-500.

Fisher, J.M. \& Raski, D.J., 1967. Feeding of Xiphinmea index and $X$. diversicaudatum. Proc. Helm. Soc. Wash. 34, 68-72.

Fuchs, M., Pinck, M., Etienne, L., Pinck, L. \& Walter, B., 1991. Characterization and detection of grapevine fanleaf virus by using cDNA probes. Phytopathology 81, 558-565.

Gambino, G., Di Matteo, D. \& Gribaudo, I., 2009. Elimination of grapevine fanleaf virus from three Vitis vinifera cultivars by somatic embryogenesis. Eur. J. Plant Pathol. 123, 57-60.

Garau, R. \& Prota, U., 1977. Morphometric identification of the juvenile stages of Xiphinema index Thorne et Allen. Nematol. Medit. 5, 349-353.
Garrett, W.N., Thompson, S.S. \& McGlohon, N.E., 1966. Nematode control in Georgia. Bulletin 652. Cooperative Extension Service, University of Georgia College of Agriculture, Athens.

Gifford Jr., E.M. \& Hewitt, W.B., 1961. The use of heat therapy and In Vitro shoot tip culture to eliminate fanleaf virus from the grapevine. Am. J. Enol. Vitic. 12,129-130

Golino, D.A., Uyemoto, J.K. \& Goheen, A.C., 1992. Grape virus diseases. In: Grape pest management, $2^{\text {nd }}$ ed. D.L. Flaherty, L.P. Christensen, W.T. Lanini, J.J. Marois, P.A. Phillips \& L.J. Wilson (eds.). University of California Division of Agriculture \& Natural Resources. Publication 3393. pp. 101-109.

Golino, D.A., 1993. Potential interactions between rootstocks and grapevine latent viruses. Am. J. Enol. Vitic. 44, 148-152.

Goussard, P.G., Wiid, J. \& Kasdorf, G.G.F., 1991. The effectiveness of in vitro somatic embryogenesis in eliminating fanleaf virus and leafroll associated viruses from grapevines. S. Afr. J. Enol. Vitic. 12, 77-81.

Goussard, P.G. \& Wiid, J., 1992. The elimination of fanleaf virus from grapevines using in vitro somatic embryogenesis combined with heat therapy. S. Afr. J. Enol. Vitic. 13, 81-83.

Harris, A.R., 1983. Resistance of some Vitis rootstocks to Xiphinema index. J. Nematol. 15, 405-409.

Hewitt, W.B., 1954. The development and spread of some virus diseases of grapevines in California vineyards. Am. J. Enol. Vitic. 5, 26-29.

Hewitt, W.B., Raski, D.J. \& Goheen, A.C., 1958. Nematode vector of soilborne fanleaf virus of grapevines. Phytopathology 48, 586-595.

Hewitt, W.B., Goheen, A.C., Raski, D.J. \& Gooding Jr., G.V., 1962. Studies on virus diseases of the grapevine in California. Vitis 3, 57-83.

Hübschen, J., Kling, L., Ipach, U., Zinkernagel, V., Bosselut, N., Esmenjaud, D., Brown, D.J.F. \& Neilson, R., 2004a. Validation of the specificity and sensitivity of species-specific primers that provide a reliable molecular diagnostic for Xiphinema diversicaudatum, X. index and X. vuittenezi. Eur. J. Plant Pathol. 110, 779-788.

Hübschen, J., Kling, L., Ipach, U., Zinkernagel, V., Brown, D.J.F. \& Neilson, R., 2004b. Development and validation of species-specific primers that provide a molecular diagnostic for virus-vector longidorid nematodes and related species in German viticulture. Eur. J. Plant. Pathol. 110, 883-891.

Izadpanah, K., Zaki-Aghl, M., Zhang, Y.P., Daubert, S.D. \& Rowhani, A., 2003. Bermuda grass as a potential reservoir host for grapevine fanleaf virus. Plant Dis. $87,1179-1182$

Jaillon, O., Aury, J. M., Noel, B., Policriti, A., Clepet, C., Casagrande, A., Choisne, N., Aubourg, S., Vitulo, N., Jubin, C., Vezzi, A., Legeai, F., Hugueney, P., Dasilva, C., Horner, D., Mica, E., Jublot, D., Poulain, J., Bruyere, C., Billault, A., Segurens, B., Gouyvenoux, M., Ugarte, E., Cattonaro, F., Anthouard, V., Vico, V., Del Fabbro, C., Alaux, M., Di Gaspero, G., Dumas, V., Felice, N., Paillard, S., Juman, I., Moroldo, M., Scalabrin, S., Canaguier, A., Le Clainche, I., Malacrida, G., Durand, E., Pesole, G., Laucou, V., Chatelet, P., Merdinoglu, D., Delledonne, M., Pezzotti, M., Lecharny, A., Scarpelli, C., Artiguenave, F., Pe, M. E., Valle, G., Morgante, M., Caboche, M., Adam-Blondon, A. F., Weissenbach, J., Quetier, F., \& Wincker, P., 2007. The grapevine genome sequence suggests ancestral hexapolidization in major angiosperm phyla. Nature, 449, 463 467

Kunde, R.M., Lider, L.A. and Schimitt, R.V., 1968. A test of Vitis resistance to Xiphinema index. Am. J. Enol. Vitic. 19, 30-36.

Lamberti, F., Roca, F. \& Agostinelli A., 1985. [The Longidoridae (Nematoda, Dorylaimida) of the Italian regions. I. Apulia.] I Longidoridae (Nematoda Dorylaimida) delle regioni italiane I. La Puglia. Nematol. Medit. 13, 21-60.

Lear, B., Goheen, A.C. \& Raski, D.J., 1981. Effectiveness of soil fumigation for control of fanleaf-nematode complex in grapevine. Am. J. Enol. Vitic. $32,208-211$

Leavitt, G.M., 2000. Diseases. In: Raisin production manual. L.P. Christensen (ed.). University of California, Agriculture \& Natural Resources. Publication 3393. pp. 162-172. 
Loubser, J.T. \& Meyer, A.J., 1987a. Resistance of grapevine rootstocks to Meloidogyne incognita examined under field conditions. S. Afr. J. Enol. Vitic. 8, 70-74.

Luc, M. \& Cohn, E., 1982. The male of Xiphinema index Thorne \& Allen, 1950 (Nematoda: Longidoridae). Revue Nematol. 5, 211-215.

Malan, A.P. \& Meyer, A.J., 1993. Interaction between a South African population of Xiphinema index and different grapevine rootstocks. S. Afr. J. Enol. Vitic. 14, 11-15.

Malan, A.P. \& Meyer, A.J., 1994. Distribution of Longidoridae in the viticultural regions of the Cape Province. S. Afr. J. Enol. Vitic. 15, 12-16.

Malan, A.P., 1995. The distribution, identity and virus vector potential of Xiphinema Spp. In the Western Cape Province. $\mathrm{PhD}$ (Agric) dissertation, Stellenbosch University. 96pp.

Martínez-Zapater, J.M., Carmona, M.J., Díaz-Riquelme, J., Fernández, L. \& Lijavetzky, D., 2009. Grapevine genetics after the genome sequence: Challenges and limitations. Aus. J. Grape \& Wine Research 16, 33-46.

McFarlane, S.A., Neilson, R. \& Brown, D.J.F., 2002. Nematodes. In: Advances in botanical research. Plumb R.T. (ed.). Academic Press, San Diego, CA, USA. pp. 169-198.

McKenry, M.V., 1992. Nematodes. In: Grape pest management, $2^{\text {nd }}$ ed. D.L. Flaherty, L.P. Christensen, W.T. Lanini, J.J. Marois, P.A. Phillips \& L.J. Wilson (eds.). University of California Division of Agriculture \& Natural Resources. Publication 3393. pp. 280-293.

McKenry, M.V., 2000. Soil Pests. In: Raisin production manual. Christensen, L.P. (ed.). University of California, Agriculture \& Natural Resources. Publication 3393. pp. 154-159.

McKenry, M.V., Luvisi, D., Anwar, S.A., Schrader, P. \& Kaku, S., 2004 Eight-year nematode study from uniformly designed rootstock trials in fifteen table grape vineyards. Am. J. Enol. Vitic. 55, 218-227.

Meredith, C.P., Lider, L.A., Raski, D.J. \& Ferrari, N.L., 1982. Inheritance of tolerance to Xiphinema index in Vitis species. Am. J. Enol. Vitic. 33, 154158.

Myles, S., Boyko, A.R., Owens, C.L., Brown, P.J., Grassi, F., Aradhya, M.K., Prins, B., Reynolds, A., Chia, J.-M., Ware, D., Bustamante, C.D. \& Buckler, E.S., 2010. Genetic structure and domestication history of the grape. www.pnas.org/cgi/doi/10.1073/pnas.1009363108. pp. 1-6.

Nicholas, P., Magarey, P. \& Wachtel, M., (eds.) 2007. Grape Production Series Nr. 1: Diseases and Pests. Winetitles, Adelaide, Australia. 106pp.

O’Bannon, J.H. \& Inserra, R.N., 1990. Nematode vectors - Transmission of plant viruses. Fla. Dept. Agric. \& Consumer Serv. Division of Plant Industry. Nematol. Circ. No. 178. 4pp.

Pearson, R.C. \& Goheen, A.C., 1988. Compendium of grape diseases. American Phytopathological Society Press, St. Paul, Minnesota. 93pp.

Pompe-Novak, M., Gutiérrez-Aguirre, I., Vojvoda, J., Blas, M., Tomazic, I., Vigne, E., Fuchs, M., Ravnikar, M. \& Petrovic, N., 2007. Genetic variability within RNA2 of grapevine fanleaf virus. Eur. J. Plant Pathol. 117, 307-312.

Prins, B.H., 1997. Resistance to the dagger nematode, Xiphinema index, in Vitis and Muscadinia species. M.S. Thesis, University of California Davis. $94 \mathrm{pp}$.

Quader, M., Riley, I.T. \& Walker, G.E., 2003. Spatial and temporal distribution patterns of dagger (Xiphinema spp.) and root lesion (Pratylenchus spp.) nematodes in a South Australian vineyard. Australasian Plant Pathol. 32, 81-86.

Raski, D.J., 1955. Additional observations on the nematodes attacking grapevines and their control. Am. J. Enol. Vitic. 6, 29-31.

Raski, D.J. \& Hewitt, W.B., 1960. Experiments with Xiphinema index as a vector of fanleaf of grapevines. Nematologica 5, 166-170.

Raski, D.J., Hewitt, W.B., Goheen, A.C., Taylor, C.E. \& Taylor, R.H., 1965a. Survival of Xiphinema index and reservoirs of fanleaf virus in fallowed vineyard soil. Nematologica 11, 349-252.
Raski, D.J., Hart, W.H. \& Kasimatis, A.N., 1965b. Nematodes and their control in vineyards. Circular 533. Division of Agricultural Sciences, University of California. pp. 1-23.

Raski, D.J., Goheen, A.C., Lider, L.A. \& Meredith, C.P., 1983. Strategies against grapevine fanleaf virus and its nematode vector. Plant Dis. 67, 335 339.

Riaz, S., Vezzulli, S., Harbertson, E.S. \& Walker, M.A., 2007. Use of molecular markers to correct grape breeding errors and determine the identity of novel sources of resistance to Xiphinema index and Pierce's disease. Am. J. Enol. Vitic. 58, 494-498.

Rowhani, A., 1992. Use of F(ab') ${ }_{2}$ antibody fragment in ELISA for detection of grapevine viruses. Am. J. Enol. Vitic. 43, 38-40.

Shurtleff, M.C. \& Averre III, C.W., (eds.) 2000. Diagnosing plant diseases caused by nematodes. APS Press. The American Phytopathological Society, St. Paul, Minnesota.

Siddiqi, M.R., 1974. Xiphinema index. CIH Descriptions of Plant Parasitic Nematodes. Set 3, No. 45 .

Siddiqi, M.R., 1979. Four new species of Xiphinema Cobb, 1913 (Nematoda : Dorylaimida) from East Africa. Rev Nematol. 2, 51-64.

Smith, P.C., 1977. Distribution of plant parasitic nematodes in vineyards in the Western Cape Province. Phytophylactica 9, 27-28.

Staudt, G. \& Weischer, B., 1992. Resistance to transmission of grapevine fanleaf virus by Xiphinema index in Vitis rotundifolia and Vitis munsoniana. Vitic. Enol. Sci. 47, 56-61.

Sultan, S.A. \& Ferris, H., 1991. The effect of soil moisture and soil particle size on the survival and population increase of Xiphinema index. Rev. Nematol. 14, 345-351.

Szychowski, J.A., M.V. McKenry, M.A. Walker, J.A. Wolpert, R. Credi \& J.S. Semancik., 1995. The vein-banding disease syndrome: a synergistic reaction between grapevine viroids and fanleaf virus. Vitis 34, 229-232.

Taylor, C.E. \& Raski, D.J., 1964. On the transmission of grape fanleaf by Xiphinema index. Nematologica 10, 486-495.

Taylor, C.E. \& Brown, D.J.F., (eds.) 1997. Nematode vectors of plant viruses. CAB International, Wallingford. Oxon, UK. 286pp.

Taylor, C.E \& Robertson, W.M., 1970. Sites of virus retention in the alimentary tract of the nematode vectors, Xiphinema diversicaudatum (Micol.) and X. index (Thorne and Allen). Ann. Appl. Biol. 66, 375-80.

Thorne, G.A., 1939. A monograph on the nematodes of the superfamily Dorylaimoidia. Capita Zoologica. 8, 1-261.

Thorne, G. \& Allen, M.W., 1950. Pratylenchus hamatus n. sp. and Xiphinema index n. sp. two nematodes associated with fig roots with a note on Paratylenchus anceps Cobb. Proc. Helm. Soc. Wash. 17, 27-35.

Torres-Viñals, M., Sabaté-Casaseca, S., Aktouche, N., Grenan, S., Lopez, G., Porta-Falguera, M. \& Torregrosa, L., 2004. Large-scale production of somatic embryos as a source of hypocotyl explants for Vitis vinifera micrografting. Vitis 43, 163-168.

Trudgill, D.L., Brown, D.J.F. \& McNamara, D.G., 1983. Methods and criteria for assessing the transmission of plant viruses by longidorid nematodes. Rev. Nematol. 6, 133-141.

Valat, L., Toutain, S., Courtois, N., Gaire, F., Decout, E., Pinck, L., Mauro, M-C. \& Burrus, M., 2000. GFLV replication in electroporated grapevine protoplasts. Plant Sci. 155, 203-212.

Valat, L., Mode, F., Mauro, M.C. \& Burrus, M., 2003. Preliminary attempts to biolistic inoculation of grapevine fanleaf virus. J. Virol. Meth. 108, 29-40.

Velasco, R., Zharkikh, A., Troggio, M., Cartwright, D.A., Cestaro, A., Pruss, D., Pindo, M., FitzGerald, L.M., Vezzulli, S., Reid, J., Malacarne, G., Iliev, D., Coppola, G., Wardell, B., Micheletti, D., Macalma, T., Facci, M., Michell, J.T., Perazzolli, M., Eldredge, G., Gatto, P., Oyzerski, R., Moretto, M., Gutin, N., Stefanini, M., Chen, Y., Segala, C., Davenport, C., DemattÃ L., Mraz, A., Battilana, J., Stormo, K., Costa, F., Tao, Q., Si-Ammour, A., 
Harkins, T., Lackey, A., Perbost, C., Taillon, B., Stella, A., Solovyev, V., Fawcett, J.A., Sterck, L., Vandepoele, K., Grando, S.M., Toppo, S., Moser, C., Lanchbury, J., Bogden, R., Skolnick, M., Sgaramella, V., Bhatnagar, S.K., Fontana, P., Gutin, A., Van de Peer, Y., Salamini, F. \& Viola, R., 2007. A high quality draft consensus sequence of the genome of a heterozygous grapevine variety. PLoS One 2, e1326.

Viglierchio, D.R. \& Schmitt, R.V., 1983. On the methodology of nematode extraction from field samples: Comparison of methods for soil extraction. J. Nematol. 15, 450-454.

Vigne, E., Demangeat, G., Komar, V. \& Fuchs, M., 2005. Characterization of a naturally occurring recombinant isolate of Grapevine fanleaf virus. Arch. Virol. 150, 2241-2255

Vigne, E., Marmonier, A. \& Fuchs, M., 2008. Multiple interspecies recombination events within RNA2 of Grapevine fanleaf virus and Arabis mosaic virus. Arch. Virol. 153, 1771-1776.

Villate, L., Fievet, V., Hanse, B., Delemarre, F., Plantard, O., Esmenjaud, D. \& van Helden, M., 2008. Spatial distribution of the dagger nematode Xiphinema index and its associated grapevine fanleaf virus in French vineyard. Phytopathology 98, 942-948.

Viry, M., Serghini, M.A., Hans, F., Ritzenthaler, C., Pinck, M. \& Pinck, L., 1993. Biologically active transcripts from cloned cDNA of genomic grapevine fanleaf nepovirus RNAs. J. Gen. Virol. 74, 169-174.

Walker, M.A., Meredith, C.P. \& Goheen, A.C., 1985. Sources of resistance to grapevine fanleaf virus (GFV) in Vitis species. Vitis 24, 218-228.

Walker, M.A. \& Meredith, C.P., 1989. The genetics of resistance to grapevine fanleaf virus in Vitis vinifera. Proc. $5^{\text {th }}$ Int. Symp. In Grape Breeding. 12-16 Sept., St. Martin. Vitis (special issue), 228-238.

Walker, M.A., Lider, L.A., Goheen, A.C. \& Olmo, H.P., 1991. VR O39-16. HortScience 26, 1226-1225.

Walker, M.A., Wolpert, J.A. \& Weber, E., 1994. Viticultural characteristics of VR hybrid rootstocks in a vineyard infected with grapevine fanleaf virus. Vitis $33,19-23$.
Walker, M.A. \& Wolpert, J.A., 1994. Field screening of grape rootstock selections for resistance to fanleaf degeneration. Plant Dis. 78, 134-136.

Walker, M.A. \& Jin, Y., 1998. Development of resistant rootstocks to control Xiphinema index and fanleaf degeneration. Acta Hort. 473, 113-120.

Walker, M.A. \& Jin, Y., 2000. Breeding Vitis rupestris x Muscadinia rotundifolia rootstocks to control Xiphinema index and fanleaf degeneration. Acta Hort. 528, 517-522.

Wang, X., Bosselut, N., Castagnone, C., Voisin, R., Abad, P. \& Esmenjaud, D., 2002. Multiplex polymerase chain reaction identification of single individuals of the Longidorid nematodes Xiphinema index, $X$ diversicaudatum, $X$. vuittenezi and $X$. italiae using specific primers from ribosomal genes. Phytopathology 93, 160-166.

Weiner, A. 7 Raski, D.J., 1966. New host records for Xiphinema index Thorne \& Allen. Plant Dis. Rep. 30, 27-28.

Weischer, B. \& Wyss, U., 1976. Feeding behaviour and pathogenicity of Xiphinema index on grapevine roots. Nematologica 22, 319-325.

Wylie, T., J.C. Martin, M. Dante, M. D. Mitreva, S. W. Clifton, A. Chinwalla, R. H. Waterston, R. K. Wilson, and J. P. McCarter., 2004. Nematode.net: a Tool for Navigating Sequences from Parasitic and Free-living Nematodes, 32: D423-D426 Nucleic Acids Research. www.nematode.net/Species. Summaries/Xiphinema.index/index.php

Wyss, U., 1978. Root and cell response to feeding by Xiphinema index. Nematologica 24, 159-166.

Wyss, U., Lehmann, H. \& Jank-Ladwig, R., 1980. Ultrastructure of modified root-tip cells in Ficus carica, induced by the ectoparasitic nematode Xiphinema index. J. Cell. Sci. 41, 193-208.

Xu, K., Riaz, S., Roncoroni, N.C., Jin, Y., Hu, R., Zhou, R. \& Walker, M.A., 2008. Genetic and QTL analysis of resistance to Xiphinema index in a grapevine cross. Theor. Appl. Gen. 116, 305-311. 